\title{
ANXIETY REDUCTION THROUGH DRAMA FOR EFL LEARNERS
}

\section{Tony Seimon}

\section{Research Institute for Social Sciences}

Corresponding author's email: tony_seimon@riss.org

While trying to find out if drama helps students' oral skills development, researchers have also found that drama lowers anxiety levels of EFL learners. Drama itself has become a teaching technique which encourages students to learn a new language in a creative and effective way. This means that drama techniques create an atmosphere where students learn in context, use their imagination, and spontaneously react. Speaking a language without any preparation is of great importance for fluency in EFL. Fluency requires performance. To achieve fluency, a learner has to perform the language. However, speaking a foreign language in the classroom is inherently artificial. It is very difficult to involve students in artificial speaking activities. Students need lifelike situations to perform the elements of the language. They also need to feel as if they are not acting. When they are aware that they are imitating a foreigner, they become anxious. Teenagers are afraid of making mistakes in front of their friends and their teachers. They feel embarrassed, anxious and humiliated. These feelings may cause reticence. When they are anxious, they can't speak. When they can't speak, they become more anxious.

Foreign language anxiety is a major element which affects performances and acquisition of FL learners. FLA occurs more in output language abilities such as writing 
and speaking than in input abilities. A high percentage of students reported that it was easy for them to become anxious when they spoke in English. Accordingly, students who tested high on anxiety, remarked that they are afraid to speak in the FL. Though the results of the study presented that speaking is the most anxiety-provoking activity in second language acquisition, half of their students reflected the use of speaking skills as confidence-building experience. Thus, it can be implied from this study that, when there is no anxiety provoking situation, speaking a FL can increase students' self-confidence. The level of self-confidence is one of the most important factors provoking anxiety because, when students experience high self-confidence, they are not afraid of making mistakes or having other students laugh at them. Besides, it was found that low selfconfidence or high anxiety levels affect students' oral performances negatively. When students are supposed to complete an oral task, their anxiety level can increase. Giving oral presentations and performing in front of other students was reported to be one of the most anxiety provoking situations.

People are often anxious about their ability in a foreign language, especially in listening/speaking situations, which leads to a type of anxiety called communication apprehension. This type of anxiety plays such a crucial role in FL speaking anxiety that even talkative people become silent in a FL class when they have communication apprehension. When FL learners continually experience FL speaking anxiety, they react physically with heart palpitation, sweating, and trembling. They also react psychologically with negative thoughts concerning language learning and speaking; having low level of self-confidence in language class; and by not looking at the eyes of 
the teacher. They may also remain silent during the lesson. At this point, what teachers are supposed to do is to create an atmosphere of low or no anxiety. Only by doing this can the student overcome the apprehension of speaking an FL.

Even though the history of drama dates back thousands of years, the use of drama in language classrooms has played a small, but consistent role in language teaching for only about four decades. Nevertheless, the advantage of this technique hasn't been completely appreciated in second/foreign language learning. The use of drama techniques fits naturally into the nature of language and language learning. In drama, there is emotion and movement, both of which have the power for liberating linguistic abilities. If drama had a place in the curriculum then its purpose must straightforwardly be the improvement of pupil's speech. Among all the positive effects of drama in ELT, improvement of speaking has a very special place. Still, as the use of drama techniques for speaking skills is relatively recent, and there is limited research on the issue, the effects of drama activities on oral skills development of FL learners hasn't clearly been put forth. It can be implied that drama changes attitudes and beliefs of students about learning a foreign language as well as speaking it in public or in FL classroom atmosphere. We can hopefully say that drama techniques psychologically and physically affect students' language abilities. Students' understanding of drama texts, their verbal knowledge, and communication skills improve. Drama keeps students active in the learning situations. Students' self-confidence and motivation increase. However, their anxiety level, which plays a major role in communicative skills in FL classes, decreases. 
References

Awan, R. U. N., Azher, M., Anwar, M. N., \& Naz, A. (2010). An investigation of foreign language classroom anxiety and its relationship with students' achievement. Journal of College Teaching \& Learning, 7(11), 33-40.

Aydın, S. (2008). An investigation on the language anxiety and fear of negative evaluation among Turkish EFL learners. Asian EFL Journal. 421-444.

Brown, D. H. (1994). Principles of language learning and teaching. USA: Prentice Hall.

Chiu, C. Y., Chang, K. C., Chen, K. Y., Cheng, W. Y., Li, P. S., \& Lo, Y. C. (2010). College students' English-speaking anxiety at the foreign language corner. Journal of National Formosa University, 29(1), 105-116.

Dalkılıç, N. (2013). The role of foreign language classroom anxiety in English speaking courses. Çukurova Üniversitesi Sosyal Bilimler Enstitüsü Dergisi, 8(8), 70-82.

Davies, P. (1990). The use of drama in English language teaching. TESL Canada Journal, 8(1), 87-99.

Dodson, S. L. (2000). FAQs: Learning languages through drama. Texas papers in foreign language education, 5(1), 129-141.

Du Mont, J. (2007). Movement \& drama in ELT. Retrieved from http://www.developingteachers.com/articles_tchtraining/dramal_juliet.htm

Dundar, S. (2013). Nine drama activities for foreign language classrooms: benefits and challenges. Procedia-Social and Behavioral Sciences, 70, 1424-1431.

Gai, F. \& Yang, D. (2010). A study on college students' anxiety to spoken English. Canadian Social Science, 6(2). Retrieved from http://www.cscanada.net, http://www.cscanada.org 
Galante, A. (2012). The effects of drama on oral fluency and foreign language anxiety: An exploratory study. (Doctoral dissertation, Department of Applied Linguistics Submitted in partial fulfillment of the requirements for the degree of Master of Arts in Applied Linguistics (TESL) Faculty of Humanities, Brock University).

Gorjian, B., Moosavinia, S., \& Jabripour, A. (2010). Dramatic performance in teaching drama in EFL context. TESL-EJ, 13(4), 1-13.

Hamilton, J. \& McLeod, A. (1993). Drama in the languages classroom. Retrieved from: http://files.eric.ed.gov/fulltext/ED382026.pdf

Horwitz, E. K., Horwitz, M. B., \& Cope, J. (1986). Foreign language classroom anxiety. The Modern Language Journal, 70(2), 125-132.

Hölzl, D. (2009). Drama and the language classroom (Doctoral dissertation, uniwien). Karakaya, E., \& Kahraman, A. (2013). Students' attitudes towards literature use and its effects on vocabulary learning. International Journal of Applied Linguistics \& English Literature,2(5), 155-166. Doi:10.7575/aiac.ijalel.v.2n.5p.155

Maclntyre, P. D., \& Gardner, R. C. (1991). Investigating language class anxiety using the focused essay technique. The Modern Language Journal, 75(3), 296-304.

Melie, S., William, G., Susanto, S., \& Nanda, D. S. (2020). Foreign language training for visually impaired students in South East Asian countries. https://doi.org/10.31219/osf.io/vjrng

Miccoli, L. (2003). English through drama for oral skills development. ELT Journal, $57(2), 122-129$. 
Nanda, Deri S., and Susanto Susanto. "THE EMERGENCE OF CYBER LITERATURE: A CHALLENGE TO TEACH LITERATURE FROM TEXT TO HYPERTEXT." EdArXiv, 21 Jan. 2020. Web.

Nanda, D. S. (2016, May). Fostering the Use of Drama for English Language Learners in the Efl Classroom. In International Conference on Education and Language (ICEL) (p. 7).

Ohata, K. (2005). Potential sources of anxiety for Japanese learners of English:

Preliminary case interviews with five Japanese college students in the US. TESL-EJ, 9(3), 1-21.

Park, H., \& Lee, A. R. (Eds.). (2005). L2 learners' anxiety, self-confidence and oral performance. 10th Conference of Pan-Pacific Association of Applied Linguistics, Edinburgh University, conference proceedings (197-208).

Susanto, S. (2016). A case study of prosodic phrasal grouping and intonational prominence in language acquisition. English Review: Journal of English Education, 4(2), 289-295.

Susanto, S., \& Nanda, D. S. (2018). Teaching and learning English for visually impaired students: an ethnographic case study. English Review: Journal of English Education, 7(1), 83-92.

Stroud, C. \& Wee, L. (2006). Anxiety and identity in the language classroom. SAGE Publications, 37(3), 299-307. Doi: 10.1177/0033688206071311

Von Wörde, R. (2003). Students' perspectives on foreign language anxiety. Inquiry, 8(1), $\mathrm{n} 1$. 
Woodrow, L. (2006). Anxiety and speaking English as a second language. SAGE Publications, 37(3), 308-328.

Wood Shand, J. (2008). The use of drama to reduce anxiety and increase confidence and motivation towards speaking English with two groups of English language learners. (Unpublished master's thesis). The University of Arizona.

Zerey, Ö. G. (2008). Impact of theater production on ELT students' foreign language speaking anxiety (Unpublished master's thesis). Mustafa Kemal University, Hatay, Turkey.

Zheng, Y. (2008). Anxiety and second/foreign language learning revisited. CJNSE/RCJCÉ, 1 (1), 1-12. 